\title{
An Interpretation of the Symbolism in The House on Mango Street in Terms of Ideational Function
}

\author{
Liu Liu and Yu Sun
}

\begin{abstract}
The House on Mango Street, a novel written by the female Mexican-American writer Sandra Cisneros in 1984, is a representative work of the Chicana Literature. The paper analyzes from the perspective of ideational function within the systemic functional linguistics, aiming to find out how the author uses these main symbolic forms in the novel to manifest the attribution and identification of the dual identity of Esperanza, a Chicana. Corpus related to these symbolic forms is collected according to the transitivity theory. Then, these linguistic evidence is analyzed with the theory of relational process, and the symbolic meanings of those symbolic forms are also combined in this process, thus revealing Esperanza's dual identity. At last, the functions of the symbolism in achieving the attribution and identification of Esperanza's dual identity are demonstrated and verified.
\end{abstract}

Index Terms-Chicana, relational process, symbolism, The House on Mango Street, transitivity theory.

\section{INTRODUCTION}

Chicano or Chicana is a chosen identity of some Mexican Americans in the United States. Chicana specifically refers to female Mexican American. The Chicano and Chicana literature flourished with the Chicano Civil Rights Movement of the 1960s. The House on Mango Street, a representative work of the Chicana literature, is a perfect combination of Chicana literature and symbolism. Therefore, interpreting the symbolism in terms of ideational function is chosen as the research subject of the paper.

Symbolism is a form of art concept that derives from the 19th century in France. According to A Glossary of Literary Terms, "Various poets of the Romantic Period, including Novalis and Hölderlin in Germany and Shelley in England, often used private symbols in their poetry......William Blake, however, exceeded all his romantic contemporaries in his recourse to a persistent and sustained symbolism -- that is, a coherent system composed of a number of symbolic elements -- both in his lyric poems and his long prophetic, or epic poems." [1] Symbolism gives a writer freedom to add dual levels of meanings to the work -- a literal one which is self-evident and the symbolic one whose meaning is far more profound. Symbolic forms are frequently used in The House on Mango Street to express the connotative voices of the Chicana. The identity of the female Mexican American is reflected and emphasized by the symbolism applied by the author. Previous researchers have mainly studied four main

Manuscript received May 24, 2017; revised July 24, 2017.

Liu Liu and Yu Sun are with School of Foreign Languages, Northwestern Polytechnical University, Xi'an 710072, PR China (Yu Sun is a corresponding author; e-mail: liuliuastrid@163.com, sunyu@nwpu.edu.cn). symbolic forms in the novel -- the house, high heels, four skinny trees, and the virgin of Guadalupe. Therefore, these four main symbolic forms are chosen to be analyzed in the paper.

The systemic functional linguistics was founded by British linguist M.A.K.Halliday. According to Halliday's work An Introduction to Functional Grammar, there are three meta-functions in any form of text, including ideational function, interpersonal function, and textual function. As to the ideational function, it consists of experiential function and logical function. Experiential function is achieved through transitivity and voice. Transitivity is a semantic system which is embodied through six processes. And relational process is one of them. The relational process relates a participant to its description or identity. The relational process is usually realized by link verbs.

\section{ANALYSIS OF THE SyMBOLIC FORMS IN THE HOUSE ON MANGO STREET}

\section{A. The Transitivity Theory}

The relational process under the transitivity theory consists of two modes -- the attributive mode (' $a$ is an attribute of $x$ ') and the identifying mode (' $a$ is the identity of $x$ '). The basic framework of relational process consists of carrier, process and attribute for the attributive mode; and identified, process and identifier for the identifying mode. There are three main types under the general mode of relational process: intensive, circumstantial, and possessive. According to [2], the framework and modes under the relational process can be further illustrated as follows:

Chicana literature often contains the theme of dual identity searching as a female Mexican American, including The House on Mango Street. The relational process concerns on the relationship between two participants from the perspective of attribute and identifying, which closely relates to the identity searching and building of the Chicana. Symbolism in this novel helps reveal this theme of identity searching, which has already been analyzed. However, using the theory of relational process can help theoretically verify the function of symbolism in expressing this theme. That's what the paper aims to achieve.

The relational process under the transitivity theory is the specific theory used to do the analysis. The relational process can be divided into two systems: identifying and attributive. According to M.A.K.Halliday, the pattern of attributive is "a is an attribute of x." The "attributive" ones are not reversible. The samples in this category mainly reflect the dual attribution of Esperanza. The pattern of identifying is "a is the 
identity of x." And the "identifying" ones are reversible. The samples in this category mainly reflect the dual identity of Esperanza. Corpus collected will be classified into this system based on the above principles.

All in all, as in [3], samples can be classified into the following six specific categories:

TABLE I: THE PRINCIPAL CATEGORIES OF 'RELATIONAL' ClaUSE

\begin{tabular}{|c|c|c|c|c|c|c|}
\hline Modes & \multicolumn{3}{|c|}{ Attribute } & \multicolumn{2}{c|}{ Identifying } \\
\hline $\begin{array}{c}\text { Intensive } \\
\text { 'x is a' }\end{array}$ & Sarah & is & wise & Sarah & is & the leader \\
\hline $\begin{array}{c}\text { Circumstantial } \\
\text { 'x has a' }\end{array}$ & Peter & has & a piano & The piano & is & Peter's \\
\hline $\begin{array}{c}\text { Possessive } \\
\text { 'x is at a' }\end{array}$ & The fair & is & on a Tuesday & The $10^{\text {th }}$ & is & tomorrow \\
\hline & Carrier & Process & Attribute & Identified & Process & Identifier \\
\hline
\end{tabular}

TABLE II: The PRINCIPAL CATEGORIES OF 'RELATIONAL' ClaUSE

\begin{tabular}{|c|c|c|}
\hline & $\begin{array}{c}\text { (i) attributive } \\
\text { 'a is an attribute of } x \text { ' }\end{array}$ & $\begin{array}{c}\text { (ii) identifying } \\
\text { 'a is the identity of } \\
\text { ' }\end{array}$ \\
\hline $\begin{array}{c}\text { (1) intensive } \\
\text { 'x is a' }\end{array}$ & Sarah is wise & $\begin{array}{c}\text { Sarah is the leader; } \\
\text { the leader is Sarah }\end{array}$ \\
\hline $\begin{array}{c}\text { (2) possessive } \\
\text { 'x has a' }\end{array}$ & Peter has a piano & $\begin{array}{c}\text { the piano is Peter's; } \\
\text { Peter's is the piano }\end{array}$ \\
\hline $\begin{array}{c}\text { (3) circumstantial ' } \mathrm{x} \text { is at } \\
\mathrm{a} \text { ' }\end{array}$ & $\begin{array}{c}\text { tomorrow is the } \\
10 \text { th; } \\
\text { Tuesday }\end{array}$ \\
\hline
\end{tabular}

And here is another table that shows the quantity and the percentage that each category plays in the samples respectively:

\begin{tabular}{|c|c|c|}
\hline & TABLE III: CORPUS DISTRIBUTION \\
quantity & $\begin{array}{c}\text { (i) attributive } \\
\text { 'a is an attribute of } x \text { ' }\end{array}$ & $\begin{array}{c}\text { (ii) identifying } \\
\text { 'a is the identity of } x\end{array}$ \\
\hline $\begin{array}{c}\text { (1) intensive } \\
\text { 'x is a' }\end{array}$ & $18 / 39.13 \%$ & $17 / 36.96 \%$ \\
\hline $\begin{array}{c}\text { (2) possessive } \\
\text { 'x has a' }\end{array}$ & $4 / 8.70 \%$ & $4 / 8.70 \%$ \\
\hline $\begin{array}{c}\text { (3) circumstantial } \\
\text { 'x is at a' }\end{array}$ & $2 / 4.35 \%$ & $1 / 2.17 \%$ \\
\hline total & \multicolumn{2}{|c}{46} \\
\hline
\end{tabular}

\section{B. Analysis of the Symbolic Forms in The House on Mango Street}

There are four main symbolic forms in the novel -- the house, high heels, four skinny trees, and the virgin of Guadalupe. And some symbolic meanings of these four symbolic forms have already been interpreted by previous researchers.

The symbolic form of house has appeared in the novel for lots of times. There are altogether six short stories that have made use of the symbolic form of house. These short stories are "The House on Mango Street," "A Rice Sandwich," "Bums in the Attic," "Alicia \& I Talking on Edna's Steps," "A House of My Own," and "Mango Says Goodbye Sometimes." Two kinds of houses are mentioned in these stories -- one is the house on Mango Street, in which Esperanza actually lives with her family, and the other is the house in her dream, the house of her own. Commonly, the house in nature is a space. According to Shi Pingping in [4], the house on Mango Street is no longer a comfortable home or a secure space; it is the shackle or cage of marriage and patriarchy for women. As for the house in Esperanza's dream, it is a symbol of the freedom and independence of women and a symbol of the American dream as well.
The symbolic form of high heels could be found in two short stories -- "The Family of Little Feet" and "Chanclas." According to Qiu Qing in [5], high heels symbolize a kind of feminine characteristic, and the gender constraint. In the male-dominated Mexican culture, some Chicanas use them as a tool or weapon to please or resist the dominated male.

In the short story "Four Skinny Trees", these four trees is commonly regarded as the embodiment of Esperanza herself, and also models for her. They give her the strength to hold on to her own dream.

The story "Born Bad" describes a Chicana image of Guadalupe, who is Esperanza's aunt. According to "Children's Point of View, Autobiography and Metaphor -Construction strategy of national identity in The House on Mango Street" by Chen Zhenjiao in [6], aunt Guadalupe and the virgin of Guadalupe share some similarities, and are both a symbol of the savior. The virgin of Guadalupe has saved the Mexican nation, and aunt Guadalupe has saved Esperanza by encouraging her to get freedom by writing.

In literary discourse, samples related to relational process can frequently be found in corpus describing a person or a thing. In this novel, only those that relate to the four symbolic forms are selected to be analyzed.

\section{1) Interpretation of the house}

The symbolic form of house is the central and most important symbolic form in the whole novel. "House" is contained in the title of the novel. From the tables below, it is easy to find that samples about the symbolic form of house account for the most among the four symbolic forms. House in nature is a kind of space, and home also takes the form of house. The symbolic form of house has a variety of symbolic meanings.

There are three symbolic meanings related to the symbolic form of the house: one is the American dream, another is the independence and freedom of Chicanas, and the last one is the root of Esperanza. Under the guidance of the relational process, many samples are found related to the symbolic form of house. The samples of the attributive mode about the house are showed as follows:

TABLE IV: ATtRIBUtive Mode ABOUT House

\begin{tabular}{|c|c|c|c|c|}
\hline & Carrier & Process & Attributive & Type \\
\hline 1 & Our house & $\begin{array}{c}\text { would } \\
\text { be }\end{array}$ & white with... (p152) & intensive \\
\hline 2 & It & 's & $\begin{array}{c}\text { small and red with... } \\
\text { (p153) }\end{array}$ & intensive \\
\hline 3 & $\begin{array}{c}\text { And the } \\
\text { front door }\end{array}$ & is & $\begin{array}{c}\text { so swollen you have to } \\
\text { push hard to get in } \\
\text { (p153) }\end{array}$ & \begin{tabular}{c} 
in \\
\hline
\end{tabular}
\end{tabular}




\begin{tabular}{|c|c|c|c|c|}
\hline 4 & I & am & $\begin{array}{c}\text { ashamed -- all of us } \\
\text { staring out the window } \\
\text { like the hungry. (p254) }\end{array}$ & intensive \\
\hline 5 & $\begin{array}{c}\text { And our } \\
\text { house }\end{array}$ & $\begin{array}{c}\text { would } \\
\text { have }\end{array}$ & $\begin{array}{c}\text { running water and pipes } \\
\text { that worked... (p152) }\end{array}$ & possessive \\
\hline 6 & And we & 'd have & $\begin{array}{c}\text { a basement and at least } \\
\text { three washrooms.. } \\
\text { (p152) }\end{array}$ & possessive \\
\hline 7 & $\ldots$ but me I & $\begin{array}{c}\text { never } \\
\text { had }\end{array}$ & $\begin{array}{c}\text { a house, not even a } \\
\text { photograph... (p277) }\end{array}$ & possessive \\
\hline 8 & & Not & $\begin{array}{c}\text { an apartment in back. } \\
\text { (p279) }\end{array}$ & circumstantial \\
\hline
\end{tabular}

And the samples of the identifying mode about the house are showed in Table V:

TABLE V: IDENTIFYING MODE ABOUT HOUSE

\begin{tabular}{|c|c|c|c|c|}
\hline & Identified & Process & Identifier & Type \\
\hline 9 & it & 's not & $\begin{array}{l}\text { the house we'd thought } \\
\text { we'd get. (p152) }\end{array}$ & intensive \\
\hline 10 & $\begin{array}{l}\text { Yes, I nodded } \\
\text { even though I } \\
\text { knew that }\end{array}$ & wasn't & $\begin{array}{l}\text { my house and started } \\
\text { to cry. (p201) }\end{array}$ & intensive \\
\hline 11 & $\begin{array}{c}\text { but I won't forget } \\
\text { who I }\end{array}$ & am & $\begin{array}{l}\text { (I) or where I came } \\
\text { from. (p255) }\end{array}$ & intensive \\
\hline 12 & ..., which & is & $\begin{array}{l}\text { home of Alicia, and } \\
\text { one day she will go } \\
\text { back there. (p277) }\end{array}$ & intensive \\
\hline 13 & No, this & isn't & $\begin{array}{c}\text { my house I say... } \\
\text { (p277) }\end{array}$ & intensive \\
\hline 14 & Like it or not you & are & Mango Street... (p278) & intensive \\
\hline 15 & $\begin{array}{l}\text {... but what I } \\
\text { remember most }\end{array}$ & is & Mango Street... (p281) & intensive \\
\hline 16 & $\begin{array}{l}\text { The house on } \\
\text { Mango Street }\end{array}$ & is & ours (p151) & possessive \\
\hline 17 & A real house that & $\begin{array}{l}\text { would } \\
\text { be }\end{array}$ & $\begin{array}{l}\text { ours for always... } \\
\text { (p152) }\end{array}$ & possessive \\
\hline 18 & I knew then I & $\begin{array}{l}\text { had to } \\
\text { have }\end{array}$ & a house (p154) & possessive \\
\hline 19 & A house & & all my own. (p279) & possessive \\
\hline
\end{tabular}

What is notable here is that two kinds of types -- intensive and possessive -- dominate the other parts of being. So, the samples mainly demonstrate the description of the houses and the relationship between the houses and their owners. Under the attributive mode, there are altogether two kinds of carriers -- the house (or some parts of the house) and "I" (or my family). As for the identifying mode, almost all the identified are related to the house.

When the house is regarded as the carrier or identified, two kinds of houses can be found -- one is the house on Mango Street where Esperanza lives with her family, the other is the ideal house in Esperanza and her family members' minds. The house on Mango Street symbolizes her origin, that is, this is the place where she grew up. Therefore, the ideal house in her heart is what she is trying to pursue. In other words, it is a symbol of the American dream to Esperanza and her family, and even all lower-class Mexican Americans. Sharp differences could be identified between the two kinds of houses: "Our house would be white with..." (clause 1), and "It's small and red with..." (clause 2). In addition, the desire for the ideal house and the disappointment for not owning it are fully expressed: "And we'd have a basement and at least three washrooms..." (clause 6), and "it's not the house we'd thought we'd get" (clause 9). It can also be seen from the link verbs used: when taking about the house on Mango Street, link verbs like "is," "am," "isn't," and "are" are used; as for the ideal house, link verbs used are "would be," "would have," and "d have" are used, which makes people realize the gap between the dream and the reality quite clearly. And link verbs like "never had" and "had to have" express Esperanza and her family's desperation. Esperanza and her family often talk about and imagine the house they want to have. The ideal decent house means a better and decent life for them and the recognition of the mainstream American society. But the process of achieving all these is difficult and painful. All in all, owning an ideal house, to both Esperanza and Mexican Americans, is their hopes, in other words, their American dreams.

Esperanza not only dreams about the ideal house with her family, but also about one of her own: "I knew then I had to have a house" (clause 18), and "A house all my own" (clause 19). The traditional Mexican society is male-dominated. Many Chicanas on Mango Street are constrained in the house of their families: some Chicanas don't have the chances to put their talents into good use, like Esperanza's mother and Ruthie; some Chicanas are abused by the male, like Esperanza's friend Sally, who is a pretty girl, being abused by her father and husband; some are imprisoned in the house by the male, like Esperanza's great grandmother and Rafaela. However, there are some Chicanas like Esperanza and Alicia, who want to live under their own roof with their own space. Sally tries to attain her own space by getting married, but she failed. Sally escapes from the house shared with her violent father to her husband's house, but there she still has to put up with her husband's bad temper and control: "She is happy, except sometimes her husband gets angry and once he broke the door where his foot went through.......Except he won't let her talk on the telephone. And he doesn't let her look out the window....." [7] Sally's experiences show that only by depending on themselves, Chicanas can get their own space and freedom. Esperanza wants to evade the typical fate of Chicanas and get freedom by using her talent -- writing. A house of her own is the symbol of the independence and freedom for Chicanas, and the process of attaining it symbolizes the realization of their own values.

Esperanza was once ashamed of the house on Mango Street and would not like to admit to belonging there: "Yes, I nodded even though I knew that wasn't my house and started to cry" (clause 10), and "No, this isn't my house I say..." (clause 13). But Alicia tells her "Like it or not you are Mango Street..." (clause 14). Then Esperanza realizes that Mango Street symbolizes her origin, that is, this is the place where she grew up, and it's what makes her who she is. She finally decides that "but I won't forget who I am or where I came from" (clause 11). At the end of the novel, Esperanza leaves Mango Street to realize her own dream, but she will come back to help those left behind and other Chicanas: "They will not know I have gone away to come back. For the ones I left behind. For the ones who cannot out." [8] She finally accepts her identity of belonging to Mango Street, and builds a bridge between who she is and who she wants to be, symbolizing the bridge between Mexican Americans and the mainstream American society. The house on Mango Street is the root of Esperanza, and will always be a part of her origin.

In terms of relational process, it can be seen clearly that, through the detailed descriptions of the real house on Mango street and the imaginary one, Esperanza is not satisfied with 
her current life and wants to become a part of another ideal world. In a sense, the house reflects a person's identity, and two kinds of different houses show Esperanza's struggle of individual identity. Through the above analysis, symbolic meanings of houses, and identity attribution and identification are revealed.

\section{2) Interpretation of high heels}

High heels are regarded as a typical element of the female image, and the symbolic form of high heels is closely related to the identity of female. In this novel, high heels symbolize the charm and power of females. The essence of this power is females' fighting against the male-dominated society. The samples of high heels under the attributive mode are showed as follows:

\begin{tabular}{|c|c|c|c|c|}
\hline & Carrier & Process & Attributive & Type \\
\hline 1 & Them & are & $\begin{array}{l}\text { dangerous, he says. } \\
\text { (p195) }\end{array}$ & intensive \\
\hline 2 & ... pretend we & are & Invisible. (p196) & intensive \\
\hline 3 & $\begin{array}{c}\text { Your little } \\
\text { lemon shoes }\end{array}$ & are & so beautiful. (p196) & intensive \\
\hline 4 & $\begin{array}{l}\text { Now you know } \\
\text { to talk to drunk }\end{array}$ & is & $\operatorname{crazy} \ldots(\mathrm{p} 196)$ & intensive \\
\hline 5 & She & is & $\begin{array}{l}\text { young and dizzy to } \\
\text { hear so many sweet } \\
\text { things in one day... } \\
\text { (p196) }\end{array}$ & intensive \\
\hline 6 & Rachel, you & are & $\begin{array}{l}\text { prettier than a yellow } \\
\text { taxicab. (p197) }\end{array}$ & intensive \\
\hline 7 & $\begin{array}{c}\ldots \text { because my } \\
\text { feet }\end{array}$ & are & ugly... (p204) & intensive \\
\hline
\end{tabular}

And the samples under the identifying mode is presented in the next table:

TABLE VII: IDENTIFYING MODE ABOUT HigH HEELS

\begin{tabular}{|c|c|c|c|c|}
\hline & Identified & Process & Identifier & Type \\
\hline 8 & Today we & are & Cinderella... (p194) & intensive \\
\hline 9 & We & must be & Christmas. (p195) & intensive \\
\hline 10 & $\ldots$ these & are & the best shoes. (p196) & intensive \\
\hline 11 & You & are & $\begin{array}{c}\text { a pretty girl, bum man } \\
\text { continues. (p196) }\end{array}$ & intensive \\
\hline 12 & You & are & $\begin{array}{c}\text { the prettiest girl here... } \\
\text { (p204) }\end{array}$ & intensive \\
\hline
\end{tabular}

In the above two tables, there are mainly two kinds of carriers and the identified -- high heels and girls wearing them. During her adolescence, Esperanza and her friends have a strong desire for owning a pair of high-heeled shoes. In "The Family of Little Feet", these young girls are given three pairs of high heels, and walk on the street with their high heels. They gets lots of attention and compliments: "Your little lemon shoes are so beautiful" (clause 3), and "Rachel, you are prettier than a yellow taxicab" (clause 6). High heels represent the charm of the female here.

On one hand, it is with the high-heels that the girls realize their own power of strong confidence. With high-heels, they confidently believe: "Today we are Cinderella..." (clause 8), and "We must be Christmas" (clause 9). On the other hand, the female use the charm brought by high heels to attract and conquer the male: "You are a pretty girl, bum man continues" (clause 11). But, just like what Mr. Benny tells Esperanza and her friends: "Them are dangerous, he says" (clause 1), the charm of high heels can be dangerous to females themselves. High heels make Rachel suffer from the harassment from a drunken bum man: "If I give you a dollar will you kiss me" [9] Chicanas intend to gain gender equality, so they need to add jetton to gain dominant right in front of the male. Esperanza and her friends choose the way of attracting males' attraction and appreciation, which is adding their feminine charms by wearing high heels. In a sense, high heels represent males' standards and expectations for charming females. The power of conquering the male is actually the ability to please the male, which means the power of the female depends on the male's recognition. High heels not only tell Chicanas' desire of gaining gender equality, but also represent the unsuccessful way by which some of them choose to gain that equality.

In "Chanclas", Esperanza wears a pair of old saddle shoes to attend her cousin's baptism party, feeling quite self-contemptuous, which forms a contrast to her confidence when wearing beautiful high heels: “... because my feet are ugly..." (clause 7), and "Today we are Cinderella..." (clause 8). Then, Uncle Nacho asks her to dance, telling her: "You are the prettiest girl here..." (clause 12). Finally, wearing that pair of poor-looking shoes, she, with her elegant and skillful dancing movement, wins not only the attentions from a boy whom she has a crush on but warm applauses from all the guests, including her mother at the party. This indicates that the true power of the female does not come from anything that they use to please the male, but themselves.

Relational process in this part mainly describes mental activities of both the female and the male evoked by high heels, which gives high heels strong symbolic meanings in a male-dominated society. These symbolic meanings reveal Chicanas' struggle of their female identity.

\section{3) Interpretation of four skinny trees}

Reference [10] shows that the four skinny trees are "four little elms the city planted by the curb." They are not only the embodiment of Esperanza herself, but also her friends and teachers. Samples under the attributive mode are showed as follows:

TABLE VIII: ATTRIBUTIVE MODE ABOUT FOUR SKINNY TREES

\begin{tabular}{|c|c|c|c|c|}
\hline & Carrier & Process & Attributive & Type \\
\hline 1 & Their strength & is & $\begin{array}{c}\text { secret. } \\
(\mathrm{p} 240)\end{array}$ & intensive \\
\hline 2 & $\begin{array}{c}\text { Four who do not } \\
\text { belong here }\end{array}$ & but are & here. (p240) & circumstantial \\
\hline
\end{tabular}

And the samples under the identifying mode are presented in the following table:

TABLE IX: IDENTIFYING MODE ABOUT FOUR SKINNY TREES

\begin{tabular}{|c|c|c|c|c|}
\hline \multicolumn{5}{|c|}{ TABLE IX: IDENTIFYING MODE ABOUT FOUR SKINNY TREES } \\
\hline 3 & Identified & Process & Identifier & Type \\
\hline 4 & They & are & $\begin{array}{c}\text { the only ones who } \\
\text { understand me. } \\
(\mathrm{p} 240)\end{array}$ & intensive \\
\hline 5 & $\begin{array}{c}\text { Four whose only } \\
\text { reason }\end{array}$ & is & $\begin{array}{c}\text { the only one who } \\
\text { understands them. } \\
(\mathrm{p} 240)\end{array}$ & intensive \\
\hline
\end{tabular}

It is obvious that carriers and the identified are mainly the four trees themselves. As in [11], The four trees share similar situations with Esperanza: "Four ragged excuses planted by the city." Planted in an abandoned Latino community, they are abandoned by the city, just like the people on Mango Street. Like Esperanza, the four trees don't belong here but have to survive here: "Four who do not belong here but are 
here" (clause 2). The four trees allude to Esperanza. Besides, under similar situations, Esperanza regards them as her friends: "They are the only ones who understand me" (clause 3 ), and "I am the only one who understands them" (clause 4). She also learns about power and toughness from them: "Their strength is secret" (clause 1), and "Four whose only reason is to be and be" (clause 5). The four trees teach her to survive and stick to her own dream. In a much broader sense, the four skinny trees are the embodiment of all the Chicanas like Esperanza, who tries to achieve her dream in a difficult situation.

Through relational process, descriptions of four skinny trees and their relationship with Esperanza are showed. The descriptions of four trees insinuate the situation and Latino identity of Chicanas.

\section{4) Interpretation of the virgin of Guadalupe}

The virgin of Guadalupe is the embodiment of all Chicanas. And she is also the savior and hope of the Chicana. Samples under the attributive mode is showed as follows:

TABLE X: ATTRIBUTIVE MODE ABOUT THE VIRGIN OF GUADALUPE
\begin{tabular}{|c|c|c|c|c|}
\hline & Carrier & Process & Attributive & Type \\
\hline 1 & Her name & was & Guadalupe... (p217) & intensive \\
\hline 2 & $\ldots$ and she & was & $\begin{array}{c}\text { pretty like my mother. } \\
\text { (p217) }\end{array}$ & intensive \\
\hline 3 & $\begin{array}{c}\text { Maybe } \\
\text { God }\end{array}$ & was & busy. (p218) & intensive \\
\hline 4 & My aunt & was & blind by then. (p220) & intensive \\
\hline 5 & That & 's & $\begin{array}{c}\text { very good, she said in her } \\
\text { tired voice. (p221) }\end{array}$ & intensive \\
\hline 6 & $\begin{array}{c}\text { Maybe } \\
\text { she }\end{array}$ & was & $\begin{array}{c}\text { ashamed. Maybe she was } \\
\text { embarrassed it took so many } \\
\text { years. (p222) }\end{array}$ & intensive \\
\hline 7 & $\begin{array}{c}\text { But I } \\
\text { think } \\
\text { diseases }\end{array}$ & have & no eyes. (p218) & possessive \\
\hline
\end{tabular}

And samples under the identifying mode is showed in the following table:

TABLE XI: IDENTIFYING MODE ABOUT THE VIRGIN OF GUADALUPE

TABLE XI: IDENTIFYING MODE ABOUT THE VIRGIN OF GUADALUPE
\begin{tabular}{|c|c|c|c|c|}
\hline & Identified & Process & Identifier & Type \\
\hline 8 & It & was & $\begin{array}{c}\text { a game, that's all. } \\
\text { (p219) }\end{array}$ & intensive \\
\hline 9 & .. but I & 'm & me. (p221) & intensive \\
\hline 10 & It & $\begin{array}{c}\text { might } \\
\text { have } \\
\text { been }\end{array}$ & $\begin{array}{c}\text { the day that gray } \\
\text { photograph was } \\
\text { taken. (p218) }\end{array}$ & circumstantial \\
\hline
\end{tabular}

It can be drawn from the above two tables that the carriers and the identified are mainly Esperanza's aunt -- Guadalupe. Esperanza's aunt has the same name with the virgin of Guadalupe: "Her name was Guadalupe..." (clause 1), which makes her a incarnation of the virgin of Guadalupe. As one of the three important female stereotypes from Mexican culture, the virgin of Guadalupe is the pillar of Mexicans: she suffers from miseries and inequality in the world with her tolerance, and she always take sides in the weak, who are poor and oppressed. Aunt Guadalupe was once beautiful: “... and she was pretty like my mother" (clause 2), but then she is tortured by diseases: "My aunt was blind by then" (clause 4). She has to face her unfair fate calmly: "Maybe God was busy" (clause 3 ), and "But I think diseases have no eyes" (clause 7). Moreover, Aunt Guadalupe helps the weak -- Esperanza, even when she is ill. When Esperanza reads her own poems to Aunt Guadalupe, "That's very good, she said in her tired voice" (clause 5). And she encourages Esperanza to gain freedom by keeping writing. She is the savior of Esperanza. In the short story "My Name", it says "In English my names means hope." [12] In this sense, Chicanas like Esperanza are the hopes of the Mexican Americans, and Chicanas like Aunt Guadalupe help preserve the hopes of their nation. At last, Aunt Guadalupe dies from diseases: "Maybe she was ashamed. Maybe she was embarrassed it took so many years" (clause 6). That's the fate of lots of Chicanas who suffer from miseries.

In terms of the relational process, the descriptions of a common Chicana -- Aunt Guadalupe, indicate her interactions with Esperanza as well. Through these, symbolic meanings of the virgin of Guadalupe and attribution of Chicanas are revealed. In short, Aunt Guadalupe is the incarnation of the virgin of Guadalupe, and the virgin of Guadalupe is the epitome and embodiment of all Chicanas, including Aunt Guadalupe. Chicanas tolerate the miseries in life and help the weak, and they are the hope and savior of the whole Mexican nation.

\section{THE IDENTIFICATION AND ATTRIBUTION OF THE DUAL IDENTITY OF ESPERANZA}

All the symbolic meanings of the four symbolic forms are presented in the table below:

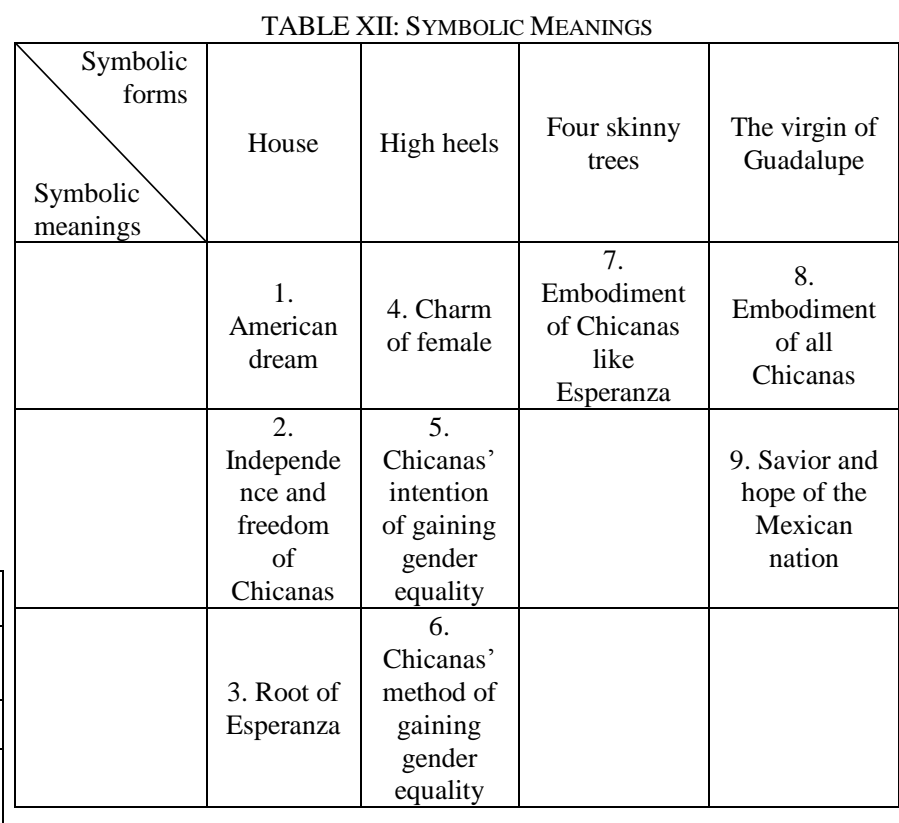

There are altogether eight connotations of the four symbolic forms. All the connotations analyzed according to the relational process are used to achieve the attribution and identification of Esperanza's dual identity. The Chicana identity itself is a kind of dual identity which can be decomposed into two parts: Mexican American identity and female identity.

\section{A. Identification and Attribution of Esperanza's Mexican American Identity}

The above symbolic meanings related to the Mexican American identity are symbolic meaning 1, 3, and 7 . According to Halliday, "Relational' clauses serve to characterize and to identify." As in [13], the intensive mode is illustrated that "this type of clause is a resource for characterizing entities serving as the carrier; and it is also a central grammatical strategy for assessing by assigning an evaluative attribute to the carrier." As in [14], "The 'possessive' clauses relate body parts to the whole and the 
'circumstantial' ones construe the extension in space of certain smaller body parts in relation to larger ones." According to [15], "In the "attributive' mode, an entity has some class ascribed or attributed to it." Halliday also states, "In the 'identifying' mode, some thing has an identity assigned to it." [16]

From symbolic meaning 1 and 3, it can be seen that as a Mexican American, Esperanza has the American dream for owning a decent house, which is one sign of integrating into the mainstream American society, which is also the American dream for all Mexican Americans. Sharing the same American dream makes Esperanza one member of Mexican Americans. Besides, the house on Mango Street is the typical house for lower-class Mexican Americans. Esperanza's accepting belonging here also means her accepting her root -Mexican American.

In connotation 6, Esperanza compares the four skinny trees to herself. The four trees are ignored by the city, just like the lower-class Mexican Americans being ignored by the mainstream American society. They are both at the bottom of society. The psychological activity of embodying the four skinny trees is the psychological activity of belonging to her social group.

\section{B. Identification and Attribution of Esperanza's Female Identity}

Symbolic meaning 2, 4, 5, 6, 8, and 9 reflect Esperanza's female identity. The female is the disadvantaged gender in society compared with the male, not to mention in the male-dominated Mexican society. In symbolic meaning 2, Esperanza wants a house of her own, which implies her wish of evading the common fates of Chicanas. In other words, she realizes that the female should be independent and not be constrained by the family. In symbolic meaning 4,5 , and 6 , through high heels, Esperanza realizes the female's charm and power, and her desire of gaining gender equality is also evoked. But, then she finds the charm and power to be dangerous and they are based on the male's recognition. In "Chanclas", Esperanza finds that the true power of the female comes from themselves.

In symbolic meaning 8 and 9, as an embodiment of the Virgin of Guadalupe, Aunt Guadalupe, an ordinary Mexican female, possesses the common qualities belonging to the Chicana group. Actually, by portraying a typical suffering Chicana, who struggles in the male-dominated Mexican-American community, this symbolic form reflects both the Mexican-American and female identity.

\section{CONCLUSION}

A transitivity analysis is conducted on the symbolic forms contained in the novel The House on Mango Street in the paper. During this process, it demonstrates how does the author use these main symbolic forms to manifest the attribution and identification of the dual identity of Esperanza, a Chicana.

It is through the four main symbolic forms in the novel that the dual identities of Esperanza are gradually demonstrated: under the precondition of preserving her Mexican-American origin, she wants to find her place in the mainstream American society, and gain her independence and freedom as a female in the male-dominated Mexican-American community. And the functions of the symbolism in achieving the attribution and identifying of Esperanza's dual identity are verified with the transitivity theory as well.

Through analyzing in terms of the transitivity theory, the Chicana identity and its attributions can be implied from the linguistic evidence contained in the four main symbolic forms. On the one hand, according to Halliday, "Thus the verbs that occur most frequently as the process of a 'relational' clause are be and have." [17] These link verbs can reflect characters' mental activities and characters' relationship with other beings. In the symbolic form of house, the usage of the link verb "have" and its variants reveals that houses can tell people's identities in a sense; the usage of link verbs of two different kinds of moods -- indicative mood and subjunctive mood, shows Esperanza's Mexican-American origin and her pursue in the mainstream American society as a female. On the other hand, as "'relational' clauses serve to characterize and to identify" [18], corpus collected under the relational process actually can reflect the identity's attributions and psychological identification, which is the identity attribution and identification of the Chicanas in the novel. Usually, after characterizing an entity's attributions, its identity will naturally be revealed. In the symbolic form of high heels, through showing the relationship between two separate entities -- high heels and young girls like Esperanza, females' position and their relationship with the male in the male-dominated society are revealed. As for the symbolic form of four skinny trees, from describing similar attributions of both these four trees and Esperanza, Esperanza's Mexican-American identity and situations of all lower-class Mexican Americans can be implied. In the last symbolic form -- the virgin of Guadalupe, through describing a typical suffering Chicana image and her relationship with Esperanza, fates of many Chicanas and Esperanza's determination of evading their fates are revealed. Symbolism makes Esperanza's mental activities of struggling with her Chicana identity the common mental activities of all the Chicanas. In conclusion, from the perspective of ideational function, symbolism contributes greatly to achieving the dual identity attribution and identification of the Chicana.

\section{ACKNOWLEDGMENT}

We would like to express our gratitude to the School of Foreign Languages of Northwestern Polytechnical University for the support.

Liu Liu also thanks her supervisor Prof. Yu Sun for her generous guidance and consistent encouragement.

\section{REFERENCES}

[1] M. H. Abrams and G. G. Harpham, A Glossary of Literary Terms, Beijing: Foreign Language Teaching and Research Press \& Cengage Learning, 2010, 283.

[2] M. A. K. Halliday and C. Matthiessen, An Introduction to Functional Grammar, Great Britain: Hodder Arnold, 2004, 216.

[3] M. A. K. Halliday and C. Matthiessen, An Introduction to Functional Grammar, Great Britain: Hodder Arnold, 2004, 216.

[4] P. P. Shi, "Open up a new space for the female's survival-An analysis of Sandra Cisnero' The House on Mango Street," Foreign Literature, no. 3, pp. 25-29, May 2005.

[5] Q. Qiu, "The women on mango street and high heels," Journal of Liaoning Administration College, vol. 11, no. 3, pp. 159-160, March 2009.

[6] Z. J. Chen, “Children's point of view, autobiography and metaphor-Construction strategy of national identity in The House on 
Mango Street," Journal of Shaoxing University, vol. 32, no. 6, pp. 59-65, November 2012.

[7] S. Cisneros, The House on Mango Street, Nanjing: Yilin Press, 2006 , pp. 271-272.

[8] S. Cisneros, The House on Mango Street, Nanjing: Yilin Press, 2006 281.

[9] S. Cisneros, The House on Mango Street, Nanjing: Yilin Press, 2006 197.

[10] S. Cisneros, The House on Mango Street, Nanjing: Yilin Press, 2006, 153.

[11] S. Cisneros, The House on Mango Street, Nanjing: Yilin Press, 2006, 240.

[12] S. Cisneros, The House on Mango Street, Nanjing: Yilin Press, 2006, 159.

[13] M. A. K. Halliday and C. Matthiessen, An Introduction to Functional Grammar, Great Britain: Hodder Arnold, 2004, 219.

[14] M. A. K. Halliday and C. Matthiessen, An Introduction to Functional Grammar, Great Britain: Hodder Arnold, 2004, 216.

[15] M. A. K. Halliday and C. Matthiessen, An Introduction to Functional Grammar, Great Britain: Hodder Arnold, 2004, 219.

[16] M. A. K. Halliday and C. Matthiessen, An Introduction to Functional Grammar, Great Britain: Hodder Arnold, 2004, 227.
[17] M.A.K. Halliday and C. Matthiessen, An Introduction to Functional Grammar, Great Britain: Hodder Arnold, 2004, 214.

[18] M.A.K. Halliday and C. Matthiessen, An Introduction to Functional Grammar, Great Britain: Hodder Arnold, 2004, 210.

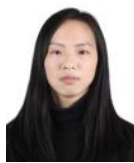

Liu Liu was born in Baoding, China, August,1993. She received her bachelor degree of arts in English, Northwestern Polytechnical University, Xi’an, China, 2016.

She is pursing the master degree of arts in Northwestern Polytechnical University in Xi'an, China, in British and American literature.

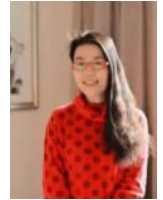

Yu Sun was born in Wuhan, China, June, 1971. Visiting Scholar, University of Maryland, America, 2014. She received her master of Arts in English language and literature, Northwestern Polytechnical University, Xi'an, China, 2000.

She is the director in the Arts Education Centre of Northwestern Polytechnical University and also the Graduate Advisor on literature and translation.

Prof. Sun is also a member of Translators Association of China and the reviewer of China Scholarship Council. 